\title{
Stigmas and Discrimination by Nurse Towards Patient With HIV/AIDS: A Qualitative Study
}

\author{
$1^{\text {st }}$ Hilda Eka Dewi \\ STIKes 'Aisyiyah Bandung \\ Bandung, Indonesia \\ jodinsajodin@gmail.com
}

\author{
$2^{\text {nd }}$ Angga Wilandika \\ STIKes 'Aisyiyah Bandung \\ Bandung, Indonesia \\ jodinsajodin@gmail.com
}

\author{
$3^{\text {rd }}$ Sajodin \\ STIKes 'Aisyiyah Bandung \\ Bandung, Indonesia \\ jodinsajodin@gmail.com
}

\begin{abstract}
The high numbers of HIV / AIDS cases in Bandung cause the necessity to optimize the quality of health services as a form of HIV / AIDS treatment and prevention. It is assumed that stigma and discrimination toward patients with HIV / AIDS among nurses affect the health care process to patients with HIV / AIDS. This study was aimed to identify the stigma and discrimination of nurses toward HIV / AIDS patients. This study used a qualitative method with a phenomenology approach. Participants were selected with purposive sampling as many as 3 participants aged 35 to 41 years. Data was collected by doing comprehensive interviews. The result of this study showed that there were three themes, they are, the nurses' knowledge about HIV / AIDS disease, the nurses' perception related to the risky behavior causing of infected HIV / AIDS, and the discrimination among nurses towards patient with HIV / AIDS. Based on the result of this study, it can be concluded that stigma and discrimination among nurses towards HIV / AIDS patients can be prevented by having decent knowledge and long-working experience. The good perception and fair behavior to the HIV/AIDS patients can reduce the stigma and discrimination to HIV / AIDS patients and improve the life quality of HIV / AIDS patients and develop the utilization of health services by the society
\end{abstract}

Keywords - Discrimination, Nurses, People with HIV / AIDS, Stigma, component.

\section{INTRODUCTION}

Stigma is something related to labeling that is given by groups or society to a disgraced person or group. A stigma can be specified to a person or people with diseases such as an infected person with HIV / AIDS. It represented in 1 study about the stigma from society against People living with HIV/ AIDS (PLWHA) which could be conceived by giving a cynical attitude and a great anxious towards PLWHA. Enormous people from the society assume that PLWHA justify to be punished as a result of what they did and be entirely accountable for infecting others with HIV / AIDS. Thus, PLWHA repeatedly receives one-sided treatment, discrimination, social isolation, ostracized or even rejected in many occasions within society such as education, occupation as well as healthy services.

It was also emphasized by 2 in Belize in his research stated that a health worker ( a doctor and a nurse) has stigma and regularly discriminates PLWHA. However, regarding to the issue, 3 identified stigma and discrimination toward PLWHA could interrupt prevention and a decent treatment for HIV since education level and the urge to participate on an HIV / AIDS training are still required to be increased by the health worker. Various misfortunes that will be experienced by people with HIV / AIDS (PLWHA) as a result of the stigma and discrimination include physical problems marked by physical changes in the patient's body system as well as psychological problems such as stress, feelings of grieving, or even depression due to the illness they suffered. According to 4, some of PLWHA have experienced psychological stress such as depressed and anxious. The PLWHA also stated that they experienced a grief feeling provoked by the rejection of PLWHA diagnosis, felt anger, blamed others and finally were in the depression stage marked by frustration, confusion, grieving, and a tendency to blame themselves. It triggered them to feel anxiety being not be able to face the next step of life namely hopeless and fear of death.

This study was aimed to identify intensely in stigma and discrimination conducted by the nurses toward the patients with HIV/AIDS. The advantage of this study is expected to be able to be references for nursing knowledge development especially stigma and discrimination of nurses towards patients with HIV/AIDS and also for knowing the nurses' stigma view to the patients with positive HIV/AIDS. The result of this identification is expected to be able to reduce the stigma itself so there will be no discrimination in conducting nursing care especially to patients with HIV/AIDS.

\section{METHODOLOGY}

\section{A. Selecting a Template (Heading 2)}

This study used qualitative research with phenomenology approach to collect the data about stigma and discrimination done by nurses toward patient with HIV/AIDS. Three participants were selected with purposive sampling. The data collection method was by doing in-depth interview conducted by the researchers themselves and the instruments used were interview guidance, stationeries, filed note and voice recorder. The reliability method used in this research to see the validity of the data was obtained by using triangulation.

\section{B. Maintaining the Integrity of the Specifications}

Based on the interview analysis result, the researcher found three themes. Those themes are a) the knowledge of nurses about HIV b) the perception of nurses related to the cause factors being infected $\operatorname{HIV}(\mathrm{s}), \mathrm{c})$ discrimination done by nurses toward HIV patients.

\section{DISCUSSION}

The feeling of fear towards HIV patients felt by the nurses is related to the knowledge level of nurses about ways of 
transmitting HIV itself. Related statements was successfully reduced, even the feeling of fear toward PLWHA has gone because they have acknowledged the process of transmitting HIV which expressed by the three participants:

"Nothing, it has been usual to face it because I have known how HIV/AIDS can be transmitted. Well, actually HIV/AIDS itself is not the thing that must be avoided but we have to be cautious on its cormobidity, but before I got the training, I always keep the distance to the HIV/AIDS patients. After getting the training, I do not do that again, I feel safe. (P2)

The anxious feeling of a disease transmission to the nurses occurs because it is influenced by knowledge, age and working experience in interacting and treating HIV patients. The statement related to the result of 5 noted in 2, Ronndahl stated that nurses with a lack of experiences show the higher level of prevention to give treatments to HIV/AIDS patients because of the fear of getting infected and feeling insecure due to lack of knowledge and experience.

In this study, it was found that there was no fear of HIV transmission and HIV patients in the participants as a nurse. That was caused by a good knowledge about HIV disease has been shared by all participants and long working experience as well as the number of frequent encounters with HIV patients, the factors that influence the lack of fear of being exposed to HIV disease and the lack of fear when interacting with HIV patients. Therefore, good knowledge about HIV / AIDS will have an impact on stigma and acceptance for people with HIV/AIDS 6.

A negative belief that nurses have for their patients suffering from HIV disease because it is constantly associated with risky behaviours such as free sex, homosexual behaviour, drug use and other bad behaviours. The result of the interview by three participants, all stated the same thing about their belief in risk behaviour by their patients, which were mentioned in the following statements:

"Yes, sometimes I feel like that because most of the patients aged junior high school visit to the hospital to be checked, those junior high students are commercial sex workers. However, most of them who has been treated here are from the community like MSM (Men who have Sex with Men).

According to the field report, most of PLWHA are believed by the participants as the result of unusual and risky behaviour such as homosexual. However, it was similar to the result of Maharani's study (2014) which talked about the stigma and discrimination of people with HIV / AIDS in health services. It stated that health workers still assume that PLWHA are untruthful and wicked. The societies similarly assume that "wicked" is seen from free sex, but the societies including health workers who have not accepted that HIV virus is transmitted not only because of "bad behavior" / "improper behavior", but it can be transmitted through blood transfusions, needles injections, and from husbands (with HIV) to wives. At the same time, the societies blame PLWHA as a source of AIDS transmission.

Discrimination can be manifested in various forms of attitudes or treatment from nurses to HIV patients such as isolating or refusing to provide the services. Thus, in this theme, the discrimination is taken from the sub-theme of physical contact that exists between nurses and HIV patients during the nursing service process. The following participant's statement stated that there was no rejection of physical contact during the counseling and treatment service: "there was no physical contact, but before counseling, we will ask about their medical history or symptoms that they experienced" (P2)

Discrimination can also be triggered by prejudice that is worsened by a bad label to someone, such as giving an unusual label to someone because of their health status that obstacle the implementation of fulfilling their basic rights as human being, in this case, receiving health services. However, giving fair healthy service to every patient is an obligation for health workers especially nurses, as the following statement stated:

"Yes, it is usual to treat the patients with HIV/AIDs, same as the other patients. They are sick people who need treatment. Give same as the other patients, don't discriminate them (P3)"

Similarly with 1 , the intended discrimination has so many forms that is related to the acceptance of PLWHA's presence such as unwillingness to have a physical contact, differentiation of treatment due to their status, and rejection from health services. Discriminative actions by health workers can be seen in diagnostic test they took without giving informed consent to the patients, they do not want to have a physical contact such as hand-shaking or basic physical check up with PLWHA and etc. Discrimination as a misfortune for PLWHA such as rejection from occupation, rejection in getting health service and differentiation of treatment for PWLHA by the health workers, abuse to PWHLA by oral or physical, sacrifices such as children with HIV/AIDs, or children whose parents who died because of AIDS, violation of human rights such as informing someone's HIV status to the others without the sufferer's permission and doing HIV test without informed consent. However, those statements are the opposite of the result of this research. The participants believed they never refuse to do physical contact with PLWHA such as hand-shaking, treat them with no different, and never refuse any patients who come to the public health center including PLWHA. Basically, the three participants have a good knowledge about the mechanism of transmission HIV, transmitted risk estimation, and the positive attitude when interacting with PLWHA. Participants as well recognized that discrimination act as an act that has its impact toward the process of treatment and the prevention of HIV diseases. There was described that stigma and discrimination has been an obstacle for PLWHA to access an optimal health care services. PLWHA refuse to consult and get afraid to inform the status.

5 mentioned that the support that has been given by the family for PLWHA to go through the hard time in the form of emotional support, appreciation, material, information and socialization because the meaningful and positive from their family can fasten the healing process and increase their selfconfidence in the future. The family needs to get involved in the process of medical and treatment as to be motivated to support their family who has HIV. In this case, someone who is so close to the patient needs to get involved as an individual who helps the patient to take care of their health such as: taking medicine regularly, choosing the food based on the patient's condition, and accompanying the patient when doing the complementary therapy to prevent stress or other possibilities. Thus, it is expected that the quality of patient's health will increase. The result of this study regarding to utilization of health care services for PLWHA was good. In this matter, nurses as health workers have supported the patients with HIV to persistently continue the medication and counseling, conduct the elimination of stigma, give better and fair services to anyone including PLWHA, make them feel 
welcome and not feeling the fear of judgment for opening up about their health status as well as routinely follow the medication and the counseling.

\section{CONCLUSION AND SUGGESTION}

The results of this study about stigma and discrimination done by the nurses toward the patients with HIV/AIDS showed that the good knowledge about HIV diseases and the nurses' working experience influence the loss of fear feeling on the nurses to treat and interact with HIV/AIDS patients. The nurses' perceptions related to the causes of HIV infection for some people and health workers (nurses) believe their views regarding the causes of HIV patients are due to "bad" behavior, such as prostitute, injecting drug abuse, and homosexuals. In this study, it can be seen all the participants believe and have the same assumption toward PLWHA that the causes of HIV is because of deviant sex behavior such as homosexual. Therefore, it can be concluded from this study that the researcher did not find stigma and act of discrimination done by the nurses toward patients with HIV/AIDS in Ibrahim Adjie Public Health Center Bandung.

Another results of this research about stigma and discrimination by the nurses toward the patients with HIV/AIDS can develop for science as a strategy to increase the knowledge for the nurses about HIV/AIDS, the level of vigilance and the loss of fear to the HIV/AIDs sufferers and a positive perception about risky behaviors that cause infected HIV/AIDS so the factors that affect the precipitation of stigma and discrimination to HIV/AID sufferers can be reduced. The further study can be conducted in health centre services that have a lot of PLWHA patients with more participants. It is shown to all health workers as a comparative materials and this study can increase the providing of health service to people with HIV/AIDS.

This study's result suggested that the implementation of trainings about HIVAIDS are more conducted by the nurses and the other health workers to increase their knowledge so the awareness of the health workers especially the nurses to HIV/AIDS in interacting will develop during the health service process. Moreover, they can remove their negative's opinion to the HIV/AID sufferers to maintain the societies' belief in the utilization of health service without reducing the patients' right as a human and discriminated behavior. Example of a figure caption. (figure caption)

\section{REFERENCES}

[1] Shaluhiyah Z, Musthofa SB, Widjanarko B. Stigma Masyaraka terhadap Orang dengan HIV/AIDS. Kesmas Natl Public Heal J. 2015;9(4):333. doi:10.21109/kesmas.v9i4.740

[2] Andrewin A, Chien LY. Stigmatization of patients with HIV/AIDS among doctors and nurses in Belize. AIDS Patient Care STDS. 2008;22(11):897-906. doi:10.1089/apc.2007.0219

[3] Urifah S. Pengetahuan dan stigma terhadap pasien HIV/AIDS di lingkungan kesehatan, Indonesia. Indones J Heal Sci. 2017;8(2):199207.

[4] Vitriawan W, Sitorus R, Afiyanti Y. pengalaman pertama pasien terdiagnosis HIV/AIDS. 2007;11(1):6-12.

[5] Rahakbauw N. DUKUNGAN KELUARGA TERHADAP KELANGSUNGAN HIDUP ODHA (ORANG DENGAN HIV/AIDS) Oleh Nancy Rahakbauw*. Insani. 2016;3(2):65-82. stisipwiduri.ac.id.

[6] Wilandika A. Pengaruh Case-Based Learning Terhadap Pengetahuan Hiv/Aids, Stigma Dan Penerimaan Mahasiswa Keperawatan Pada Odha. J Pendidik Keperawatan Indones. 2017;3(1):1 doi:10.17509/jpki.v3i1.7474 